\title{
2. Welfare state regimes, family policies, and family behaviour
}

Gerda Neyer

\section{INTRODUCTION}

The past three decades saw an enormous increase in research on welfare states, family policies, and families. There is hardly any comparative or single-country study on European families that does not refer to welfare states or family policies. The rapid growth of the field is also reflected in the large number of handbooks on family policies, the welfare state, and social policies that have been published during the past decade (e.g., Blum et al 2019; Castles et al. 2010; Eydal and Rostgaard 2018; Greve 2019; Robila 2014; Shaver 2018). Given the enormous body of literature and the breadth of topics covered in this research field, this contribution must be limited to specific aspects of it. The main purpose of this chapter is to provide an overview of the developments and the core research in this area, and to outline some new directions for family research. The chapter is further limited by its primary focus on research on European welfare states, and on Western European countries in particular. Chapters in other handbooks on family policies, welfare states, and social policies usually provide overviews of developments in family policies, of differences in policies across welfare states, or of employment-care regulations in different welfare regimes or welfare states. To complement these contributions, the present chapter also deals with the influence of welfare states and family policies on family behaviour and family outcomes. In particular, it addresses the methodological issues involved in such research. Throughout this chapter, family behaviour refers to family events, such as childbirth, or union formation. Family outcomes refers to aggregated measures of family issues, such as the total fertility rate, or the share of childlessness in a society. The examples in the methodological section of this chapter are primarily taken from quantitative family demographic research, with a focus on parental leave and childcare policies. Theoretical discourses on the links between welfare states, family policies, and families have focused on these two policies. Moreover, parental leave and childcare policies have also formed the core of family and gender policy initiatives at the European Union (EU) and national levels. The chapter first presents a very abridged summary of research prior to Esping-Andersen's influential work on welfare regimes with the aim of noting the scientific approach that the conceptualisation of welfare regimes brought to social research on welfare states, family policies, and families. This is followed by a presentation of methodological issues and examples of quantitative research on the association between welfare states, family policies, and families. The chapter concludes with a discussion of new research directions that are made necessary by changes in welfare states. 


\section{COMPARATIVE WELFARE STATE RESEARCH - ORIGINS AND DEVELOPMENTS: THE FAMILY IN EARLY WELFARE STATE RESEARCH}

The welfare state has its roots in the family. This statement may come as a surprise to some readers, since most welfare state research associates the birth of the welfare state with the introduction of compulsory health, accident, invalidity, and old-age insurance schemes in Germany in the 1880s. However, the first welfare state policies enacted in the first half of the nineteenth century targeted widows and orphans, as well as working women and children. At that time, there were growing concerns about how the loss of the main earner in a family, or children and women working in factories, might affect the health of the working-class families and of future generations, as well as men's working conditions and wages. These concerns led to the introduction of the first welfare state measures, such as limitations on working hours, restrictions on health-endangering work by children, prohibitions on women working after childbirth, and widows' pensions (Kessler-Harris et al. 1995).

Despite the essential role that family issues played in the foundation of the welfare state, research on the welfare state has often failed to deal with the family in its own right. Most welfare state studies focused on the role social policies played in addressing the consequences of capitalist production. Social policies were seen as a means to relieve the family of having to bear the costs of economic changes through social insurance and the protection of the male worker and his income (see, e.g., Flora and Heidenheimer 1982a; Wilensky 1975). This line of research recognised the need to analyse social policies with respect to their redistribution and their equality aims; i.e., whether social benefit claims can be made on the basis of social citizenship, and whether social policies are designed to provide equal opportunities or equal outcomes (Flora and Heidenheimer 1982b).

Feminist social scientists of the 1970s and 1980s turned the focus of welfare state research towards the family. Their core concern was how welfare states regulate family lives, and women's lives in particular. Specifically, they looked at how welfare states acknowledge reproduction and women's unpaid work, and either bind women to or relieve them from family work and dependence on men. Continental European and Scandinavian feminists tended to view the welfare state quite differently. This was partly because most researchers analysed the social policies and welfare state orientations of the country in which they lived. Moreover, feminist researchers had a scientific as well as a political agenda. Identifying and analysing the specifics of the family blindness, gender bias, and patriarchal nature of each welfare state were integral to the efforts of feminists to change the welfare state and the conditions of women's lives. German researchers, for example, argued that the welfare state privileges the male breadwinner and marriage by familialising women, cementing gender inequalities in the family and in work, prolonging women's dependence on their husbands, and contributing to women's poverty throughout the life course (see, e.g., Kickbusch and Riedmüller 1984). Scandinavian feminists, by contrast, saw the welfare state as a potential source of power for women in their struggle to achieve gender equality in the family and in the public sphere. They argued that a woman's dual role as family carer and worker makes her more dependent on the welfare state than a man, and that the welfare state could be an ally for women in their struggle to become independent of men. The goal of feminist research and political activism should therefore be to work towards a 'women-friendly welfare state' that supports a gender-equal division of work and family obligations (see, e.g., Hernes 1987). 


\section{THE THREE WORLDS OF WELFARE: A COMPARATIVE FRAMEWORK}

Feminist welfare state research viewed the welfare state from the perspective of women's status in the family. In this sense, it moved the family to the centre of welfare state research. Esping-Andersen (1990) integrated the family conceptually into his comparative framework of welfare regimes in his seminal book The Three Worlds of Welfare Capitalism. Through his work, Esping-Andersen made several path-breaking contributions to the research field. First, he viewed the state, the market, and the family as interlocked in the provision of welfare. Second, he grouped European welfare states according to the intentions of their social policies and the principles on which they were based. Third, he moved welfare state research from a focus on national social policies to a focus on the common features that characterise different welfare regimes. Fourth, he provided a basis for comparative welfare state research that became the dominant research approach in the subsequent decades. His classic distinction between social-democratic or universalistic welfare states (the Nordic countries), conservative-corporatist welfare states (continental Western European countries), and liberal welfare states (Anglo-Saxon countries) has become a common reference point in social science and family research involving welfare states.

Viewed from a family research perspective, social-democratic welfare states seek to promote social equality and the independence of individuals from family support. In these states, social policies are individual-based and social service-oriented. The aims of these policies are to relieve the family of the obligation to provide welfare, to reduce social and employment-related risks, and to provide high living standards for everyone. Most social security benefits are granted on the basis of individual social citizenship rights, usually independent of family relations and of the economic capacities of other family members. Conservative welfare states direct their social policies towards status maintenance and the preservation of traditional family forms. In these states, social benefits correspond to work performance, as measured by the level and the duration of contributions to social security systems; or they depend on marriage. Conservative welfare states rely heavily on the family as a provider of welfare and social services. Liberal welfare states encourage market-based individualism by providing minimal social benefits and by subsidising private and marketised welfare schemes. In these states, social benefits are usually means-tested and poverty-related, and social services are market-based or privately provided.

Some researchers have argued that continental Western European countries are too diverse to be grouped into a single conservative-corporatist welfare regime. It has, for example, been pointed out that due to their stronger reliance on kin and their clientelism, Southern European welfare states could be viewed as representing a separate Mediterranean or Southern European welfare regime (Ferrera 1996). It has also been observed that the Netherlands and Switzerland deviate from the ideal conservative-corporatist regime type, and could thus be characterised as hybrid liberal-conservative welfare states (Arts and Gelissen 2002). Post-communist Eastern European countries have been added as distinct Eastern European regime types (Cerami and Vanhyusse 2009). East Asian and Latin American countries are increasingly viewed as representing either separate welfare regimes (e.g., the Confucian welfare regime in East Asia) or regimes that are developing in the direction of one of the classic welfare regimes (Robila 2014; Arts and Gelissen 2010). 
Esping-Andersen built his original typology on three principles. The main principle is de-commodification. This is also the primary principle governing the modifications and extensions of the three core welfare regimes. De-commodification is the extent to which social policies reduce workers' dependence on the market, generally by providing workers with the right to claim social security benefits so that they can support themselves without having to rely on the market. The other two principles are stratification, which refers to the extent to which social policies promote and maintain class structures in society; and social citizenship, which refers to whether access to social benefits is granted as an individual right, or is based on need (Esping-Andersen 1990).

\subsection{Bringing Family Policies and Families into Welfare Regime Research}

Feminist and gender researchers have pointed out that these principles and the classification of welfare states were primarily based on labour market and class perspectives. The family remained a residual category, not least because the typology of welfare regimes was mainly built on social policies that cover old age, sickness, and unemployment. Family policies, including those related to de-commodification, such as maternity leave or parental leave, were not taken into account. As a consequence, the family was seen as disconnected from welfare state policies and the labour market. Family and gender issues were viewed as private, apolitical matters, and thus vanished from welfare state analyses. In line with their approaches to social policy and family research in the 1970s and 1980s, feminist and gender researchers moved the family, gender, and family policies to the centre of welfare state classifications and integrated them into the welfare regime typology (e.g., Lewis 1992). These researchers introduced core principles that govern welfare state and family policy approaches to families and gender: commodification, that is, the extent to which family policies constrain or support the employment of women, and especially of mothers (Orloff 1993); dependence on or independence of social security, that is, whether social security coverage and social and family benefits are granted to each family member on the basis of individual social citizenship rights, or whether (non-employed) family members depend on a (male) breadwinner's coverage (Langan and Ostner 1991; Lewis 1992); care as an essential component of family and welfare state provision (Knijn and Kremer 1997); and familialisation or de-familialisation, that is, the extent to which welfare states relieve the family of care responsibilities or support family care directly or indirectly through family policies (Esping-Andersen 1999; Leitner 2003). Incorporating these dimensions into welfare state classifications and viewing 'welfare regimes through the analytical lens of the family' (Esping-Andersen 1999, p. 49) has significantly advanced comparative welfare state, family policy, and family research. Three aspects of this shift are particularly noteworthy, as they altered how family policies and families are conceived.

First, family policies are now considered a central constituent of a welfare state, alongside other social policies. Analyses of welfare states or of welfare regimes usually include, or at least acknowledge, family policies; for example, in investigations of or reflections on the extent to which different welfare states stratify society or contribute to social (in)equality. Likewise, analyses of family policies usually consider the welfare state or welfare regime context in which the policies are situated in order to properly assess the range or consequences of family policies. 
Second, the perception of family policies has changed. Kamerman and Kahn (1978) defined family policies as everything that government does to and for the family. They saw them as the sum of all state activities directed towards the family. Based on this notion, family policies are usually assessed according to their 'generosity', such as the share of the gross domestic product devoted to these policies or the share of social spending allocated to families. Researchers now highlight the structuring function of family policies and the principles and aims on which they are based. They focus on how family policies shape gender, class, race/ ethnicity, and other social, economic, and private relationships in society and the cultural and ideological understandings of family and gender behaviour (Pfau-Effinger 1998, 2005). In essence, they define family policies as those that structure the labour market and society by structuring family life and family behaviour along gender lines. Rather than using a compound measure for family policies, they assess the aims, functions, and effects that different family policies have on individuals, families, and society (see, e.g., Gornick and Smeeding 2018; Thévenon 2011).

Third, since different family policies address different family issues, the family is no longer conceived of as a single entity. Instead, researchers have distinguished between the different relationships of which families are composed, such as partnerships and parenthood, and, increasingly, intergenerational relationships (Saraceno 2008). They have further distinguished between different family forms, such as marriage, cohabitation, same-sex partnerships, dual or single parenthood, and complex or reconstituted families, and have assessed to what extent family policies prioritise specific family forms, ease or hamper specific family behaviour, and acknowledge family diversity.

The classification of welfare regimes becomes more diverse if family policies and their structuring functions of family behaviour are taken into account, including how they have changed over time. As women's levels of education and employment have increased, gender roles have changed, non-marital childbearing and sole parenthood have become more common, fertility levels have decreased, and populations have grown older, the focus of family policies has shifted away from providing cash benefits and income supplements towards facilitating workfamily reconciliation. The developments in cash-centred family policies and in work-family reconciliation policies have not been uniform across Europe (see, e.g., Daly and Ferragina 2018; Ferrarini 2006; Gauthier 2002; Gornick and Meyers 2003; Morgan 2012). Due to the EU Directives on parental leave and work-life balance for parents and carers, all EU member states have implemented gender-neutral parental leaves. However, across the EU member states, these leaves vary substantially in terms of duration, type (flat-rate or income-based), and financial compensation levels, qualification criteria, and incentives for fathers to participate in care (International Leave Network, www.leavenetwork.org; Moss et al. 2020). Parents also have the right to request flexible working arrangements, and to take care leave if their child has special care needs. Moreover, the EU encourages member states to provide leave benefits to individuals who are caring for relatives other than children. The policy options and conditions for these benefits again vary greatly across the EU member states (see International Leave Network, www.leavenetwork.org).

The Barcelona Target of 2002 called for EU member states to provide childcare for 33 per cent of children below age three and for 90 per cent of children between age three and school entry age by 2010 . While the rates of enrolment in formal childcare (public, private, or childminders) have indeed increased, particularly for children aged $0-2$, the levels of coverage still vary substantially among countries. In several countries, the enrolment rates are far 
below the target, and the hours of childcare available to families also differ greatly (Rostgaard 2018). The different patterns of converging and diverging family policy developments across European countries, and the great diversity and often ambivalent or contradictory work-family orientations of family policies within each country, make it difficult to compare countries and to classify them into regimes.

Researchers have mainly concentrated on three policy directions: first, policy support for women's employment and work-life balance; second, the availability of social care services and de-familialisation; and, third, policy support for dual earner-dual carer families and for gender role changes. Initial studies used these family policy features to assess the consistency of Esping-Andersen's three worlds of welfare. These authors proposed different regime classifications: e.g., gender regimes; care regimes; male breadwinner, earner-carer, and dual earner-dual carer regimes; and direct and indirect familialisation regimes (see, e.g., Leitner 2003; Sainsbury 1999; Saraceno and Keck 2010). A large body of literature has since investigated whether changes in family policies or the inclusion of other family-relevant aspects - such as class, education, occupation, poverty rates, gender wage gaps, agency inequalities or capability sets - lead to different regime constellations (see, e.g., Hobson and Fahlén 2009; Korpi 2000; Korpi et al. 2013; Mandel and Semyonov 2005). All of these studies have found surprisingly consistent patterns of welfare state classifications, but also variations in patterns depending on which family policies or policy packages are analysed.

Researchers commonly find that the Nordic countries and the liberal welfare states differ from the continental conservative and Mediterranean welfare regimes. The Nordic countries generally support gender-equal participation in work and care. They most consistently de-familialise care by providing universal coverage of institutional care for both children and the elderly. However, the once homogeneous orientation towards the gender-equal earner-carer family has been somewhat eroded through the introduction of care leave benefits in Finland (1990) and in Norway (1998). In liberal welfare states, work-family balance depends more on the financial and employment circumstances of the individual or the family, and on market-provided care. Among the continental conservative Western European welfare states, researchers commonly distinguish between several groups: Belgium and France, which have a long tradition of supporting mothers' employment. They offer extensive day care and pre-school for children, and de-familialise care to a greater extent than other continental European countries. Germany and Austria, which used to support the gendered division of work and care but shifted away from a focus on familialising policies, albeit to differing degrees. In 2007, Germany replaced its care leave by an income-related parental leave. Between 2000 and 2010, Austria extended and layered its care leave and added an income-related parental leave option (Leitner 2011). Both countries still rely heavily on care provided by the parents, as institutional childcare is mainly available on a part-time basis only. Southern European countries offer little support for mothers' employment or for work-life balance. They neither de-familialise nor explicitly familialise childcare through their family policies (Saraceno 2016). The family policies of the Netherlands and Switzerland lie between those of the liberal and conservative regimes. The work-life family policies of Eastern European countries have oscillated between familialising and gendering work-life balance by providing long periods of leave, and supporting employment-oriented family behaviour by providing income-related parental leave benefits. Most Eastern European countries de-institutionalised childcare and have low childcare coverage (Saxonberg and Sirovátka 2006). Overall, in Europe, family policies concerning care for young children seem to converge towards facilitating familialised 
care through parental leave benefits, complemented with institutionalised care provided by care services (Daly and Ferragina 2018; Gauthier 2002). The parental leave regulations of the European countries include options for fathers to provide care, but the majority of European countries do not directly and consistently promote greater gender equality in the family and a de-gendering of men's family behaviour. The familialisation of care is even partly associated with a re-gendering of care, as the countries with the longest parental leave periods (especially in Eastern Europe) offer the fewest options for fathers to take leave (see, e.g., the contributions in Eydal and Rostgaard 2018).

A new development in family care arrangements in Europe that lies in-between marketised or state-supported forms of familialisation and de-familialisation is the recent growth in transnational care services, especially for elderly care. Several Western European welfare states, such as Austria, Italy, Germany, Italy, Spain, the Netherlands, Finland, and Sweden, have introduced tax breaks or cash benefits for those in need of care or home help (Williams 2012). This care is often provided by female migrant care workers from Eastern European countries. These workers frequently live with the person or family they are caring for, leaving their own family behind in their home country. These care services constitute new marketised, privatised, or institutionalised transnational forms of care that occupy a space between the 'familialisation' of care in Western countries and the 'de-familialisation' of care in Eastern European countries (Williams 2012; Hobson et al. 2018; see also Merla et al. in this volume).

Given the ambiguities in family policies and the development of transnational care services, researchers have pointed out that when shifts occur in the family policy schemes of a country, efforts to classify the family policies into family policy regimes should take into account the degree to which a country simultaneously provides forms of gender segregating and familialising family support, such as cash, tax, or care leave benefits; and gender-equity and employment-oriented support, such as income-related parental leave and high levels of childcare coverage (Ferrarini 2006; Korpi et al. 2013). Such distinctions can provide a more nuanced picture of how family policies vary within or across welfare regimes.

Viewed from a family research perspective, gender- and family-oriented welfare state researchers have introduced the family in a more subtle way into welfare regime classifications. They have shifted the focus on the employment-care nexus as the core of welfare state policies, and have put the emphasis on the conditions that welfare states and family policies set for human agency. These contributions have broadened the range of research on the links between welfare states, family policies, family behaviour, and family outcomes; in particular by theoretically linking the institutional context (welfare state) and its policy instruments (family policies) to individual behaviour and outcome.

\section{ANALYSING WELFARE STATES, FAMILY POLICIES, AND THE FAMILY}

\subsection{The Welfare State and the Family}

Esping-Andersen (1990) laid the groundwork for new approaches in comparative welfare state research by basing the classification of welfare states on common dimensions. The welfare regime concept captures the institutional configurations of welfare states and their normative underpinnings with respect to stratification and social equality, social rights, and 
de-commodification principles. Gender and family policy researchers have shown that welfare state and family policy regimes are aligned, albeit to varying degrees, depending on the country and on the family policies that are included in the regime classification. While these similarities and differences broaden the scope for family research, some limitations can also be observed.

First, unlike family policies, which may be amended, reformed, or abolished, welfare states have what Pierson calls 'institutional stickiness' (Pierson 2001). They tend to change slowly and incrementally. Even if they undertake radical and paradigmatic reforms in some policy areas, countries usually remain in their respective welfare regimes. Thus, a country's welfare regime can be seen as providing a comprehensive and structured description of the long-term institutional arrangements and the contextual conditions in a country. Because of the principles on which they are based and their cultural underpinnings, welfare regimes provide an analytical and theoretical framework for comparative, cross-country, and single-country studies of family behaviour and family outcome. However, their comprehensiveness and path persistence also make it difficult to observe and measure the direct influence of welfare states or welfare regimes on individual family behaviour (Mayer and Schöpflin 1989).

There are basically three ways in which welfare states or regimes have been applied in family research. First, in multi-country comparative family research, welfare regimes have been used to explain differences in family outcomes across countries by attributing them to the different welfare regime contexts. In this line of research, welfare regimes enter research a posteriori, in the interpretation of country-specific results. These studies implicitly or explicitly start with the assumption that welfare states structure life courses (Mayer and Schöpflin 1989; see also Konietzka and Kreyenfeld in this volume). Therefore, similar contextual conditions should result in similar family patterns in countries that belong to the same welfare regime, and family outcomes should vary across countries that belong to different welfare regimes.

A second line of family research uses welfare regimes to compare family behaviour or family outcomes in a structured research design. These authors commonly apply a 'most-different' or a 'most-similar system design' approach (Przeworski and Teune 1970). In the most-different system design approach, researchers either select one or more countries from each welfare regime as representatives of the respective regime - e.g., Germany, Sweden, and the United Kingdom - or they pool the data of the countries belonging to the same welfare regime to analyse family behaviour or family outcomes across welfare regimes. In this line of research, welfare regimes enter research a priori, in the selection of or the pooling of countries for the analyses. The assumption of researchers using a most-different system design is that family behaviour or family outcomes should vary across the countries or country clusters that represent the welfare regimes, because of the different institutional and cultural contexts that these regimes provide for families. Researchers who apply a most-similar system research design usually investigate family behaviour or family outcomes in countries that belong to the same welfare regime. Similar results for these countries could then be interpreted with reference to the similar welfare state conditions, or taken as an indicator for the structuring strength of the welfare state vis-à-vis other behaviour-shaping institutions, such as religion. Differences in the results across the countries would signal that other social, cultural, or economic forces were at work that produced the different family outcomes.

A third line of research investigates family behaviour or outcomes in a single country. The reference to the welfare regime to which this country belongs serves as a summary of the contextual conditions in this country. It also places the country within a larger context 
(especially if the country is small, and is, therefore, not one of the large European countries that receive considerable attention from researchers). Situating the country within the broader welfare regime concept increases the options for interpreting the results. The findings can be interpreted as country-specific; but they can also be used to draw inferences about other countries belonging to the same welfare regime. Finally, interpreting the findings from a welfare perspective can reduce the temptation to universalise results that are specific to this particular country or welfare regime.

\subsection{Family Policies and the Family}

Research on the links between family policies and families may be broadly categorised into two groups: one group of studies that focus on the macro-level relationship between family policies and family outcome, and another group of studies that take an individual-level approach. Some of these studies explore explicitly how family policies shape family behaviour, while other studies do not investigate the role of family policies directly, but simply refer to family policies when seeking to explain certain family behaviour. The approaches of these two groups differ in terms of design, methodology, and explanatory range with respect to family behaviour.

Macro-level approaches assess the association between aggregate indicators of family policies and of (macro-)family outcomes. Among the indicators commonly used to assess family policies are, for example, spending on families in total; cash allowances, tax breaks, or services; the number of paid weeks of maternity or parental leave; the income replacement rate during maternity or parental leave; the enrolment rate of children of different age groups in public childcare; and the level of marriage or birth subsidies. The unit of analysis is usually the national level. In this area of research, there are three major approaches. The first is exploratory and seeks to find a tentative explanation for cross-country differences in family outcomes by looking at family policies. This line of research may be connected to presenting a new database, or a systematic collection of policies or descriptions of country policies that have not been available before (see, e.g., Saraceno and Keck 2010). Another, partly overlapping line of research aims to provide empirical evidence for theoretical assumptions about the correlation between family policies and family outcomes, such as the link between a country's spending on childcare and women's employment. These studies provide an indication that the family policies and family outcomes covered in the study may be related to each other. However, as is well known, many fallacies can arise when using macro-correlation to make causal claims.

In studying the link between family policies and family behaviour, researchers are confronted with a number of methodological issues that make conducting this research both intriguing and difficult. Hoem (2008) and Neyer and Andersson (2008) have discussed these issues with respect to the impact of family policies on fertility. Their insights also apply to other aspects of family behaviour. Hoem (2008) identified four methodological challenges. The first concerns data and measurement issues. Aggregate data, like period rates (e.g., period total fertility rate, annual female labour force participation rates) are rather broad and insufficient measures for assessing the impact of policies on behaviour. The second issue is that the cause-effect relationship may be reversed. Policies may be enacted because of a demand or an ongoing or anticipated development. Failing to account for this possibility may lead to false conclusions or to an overestimation of an effect. A third problem is that there are often no counterfactuals that would allow researchers to assess what would have happened if the 
policy had not been introduced. In the absence of a true counterfactual, it is difficult to measure the true strength of a policy effect. Hoem (2008) used findings from studies on the effects of parental leave benefits in Sweden and care leave benefits in Finland during the economic crisis of the 1990s to illustrate the problem. He argued that the Swedish income-related parental leave policy led to the decline in fertility during the economic crisis; while the Finnish home care allowance, which could be taken up to a child's third birthday, prevented a decline during the economic crisis. If a researcher had only studied the effect on fertility of the home care allowance in Finland, s/he might have concluded that it had no impact on childbearing, as fertility had remained rather constant over the observation period.

The examples of fertility developments in Sweden and Finland during the economic crisis may also serve as an example of the fourth problem that Hoem (2008) addresses: namely, that policies operate within specific contexts. Thus, the effects of policies on family behaviour cannot be isolated from the social, economic, cultural, and policy contexts in which they are embedded. Even identical policies enacted in different welfare states may not have the same effects (Neyer and Andersson 2008). By extension, if similar family policies are found to have similar effects in different welfare states, this observation may strengthen the assumptions about a causal connection between the family policy and behaviour. Disentangling the cultural, economic, and policy contexts in order to determine the influence of a specific family policy on family behaviour remains challenging for family researchers. These difficulties may be due not only to data availability and methodological issues, but to the policy and the policy process itself. For example, a family policy may have been implemented or amended together with other policies that may also affect family behaviour. Such 'policy packages' are often used to tackle an economic crisis. However, it may be difficult to isolate the effects of family policies that were concurrently implemented with other social policies. Moreover, policies may be designed for purposes other than to address family issues, and they may be designed to have no effect. Alternatively, policies could have unintended consequences for family behaviour. Thus, having detailed knowledge of the design, history, and implementation of policies is a prerequisite for being able to disentangle the contextual and policy effects.

To reduce the complexity of studying the effects of family policies, Neyer and Andersson (2008) have presented several strategies related to different types of family policies. One approach is to study whether a significant policy change, a so-called 'critical juncture' (Hall 1993; Thelen 1999), alters family behaviour; and conversely, whether a significant change in environmental conditions affects family behaviour. A much cited example of the effect of a critical juncture is the 'speed premium' in Sweden, whereby parents shortened their birth intervals after a reform of parental leave regulations that benefited parents who had their second or subsequent child within a certain period of time after the previous birth (Hoem 1993). An extension of parental leave in Austria from one to two years had a similar, albeit unintended effect on birth spacing (Lalive and Zweimüller 2009). Economic crises, like those in Sweden and in Finland in the 1990s or the Great Recession, are classic 'critical' events that lend themselves to studying the effects of family policies on family behaviour under different conditions.

Recent findings also indicate the need to study the sequencing of 'critical junctures' in order to properly assess the impact of family policies on family behaviour. Duvander and Johansson (2012) showed that two reforms of the Swedish parental leave designed to encourage fathers to take leave had different effects on fathers' uptake of leave, and on the social differences among the fathers who took leave. In a comparison of fertility trends after the economic crises in the 
1990s and the Great Recession of 2008 in the Nordic countries, Comolli et al. (2021) found that there were rather different reactions to the crises in childbearing in the various Nordic countries and in the different educational groups. This study also illustrates the importance of carefully considering the interactions between family policies and other social and economic developments, and of assessing them in a wider context.

The critical juncture approach may not be suitable or may have to be modified for investigations of family policies that develop incrementally. For example, if a policy like parental leave is introduced step-wise, the researcher needs to interpret the development of family behaviour over the entire implementation period in order to understand the potential impact of the policy change. Applying a critical juncture approach is also not appropriate if policies develop 'unevenly' across regions, such as the provision of childcare. In cases like these, the spatial variation across regions or municipalities can be exploited (Andersson et al. 2004; Neyer and Andersson 2008).

A fourth issue that can arise concerns the uptake of family policies. A number of studies have investigated how taking advantage of a policy can affect family behaviour. To conduct this kind of research, variation over the study population is needed. For example, the family behaviour of those who take advantage of a policy, receive a benefit, or participate in a programme may be compared with the family behaviour of those who do not. A similar approach is to explore whether family behaviour differs by the duration of uptake, the length of participation, or the benefit level (Duvander et al. 2019).

A fifth issue to consider is that family policies are not uni-directional (Korpi 2000). The different family policies of a country may pursue different aims, and may be ambiguous or even contradictory. For example, while high levels of cash benefits for children or tax reductions for a sole earner can prevent poverty, they may also discourage the uptake of employment if the economic gains from employment are marginal due to low wages and high childcare costs. In general, quantitative studies on the effects of family policies on family behaviour do not account for such ambivalence, not least due to the lack of proper data. However, as family policies become more diverse, there is a need to develop family research in the direction of simultaneously contradicting policies when studying the effect of family policies on family behaviour.

The examples and methodological considerations above relate to quantitative research. Apart from data issues, quantitative policy research also suffers from the problem that studies that find that policies have no effect are seldom published, even if the data and the modelling are outstanding. This 'publication bias' greatly limits our understanding of how welfare states, family policies, and family behaviour are interlinked from both a research and policy-making perspective. Qualitative research can partly fill this gap. The advantage of using a qualitative approach in policy research is that it allows researchers to consider aspects that are often not available in surveys or register data, such as personal circumstances, family characteristics, workplace or network relationships, cultural and normative considerations, and details or interactions of policies that may facilitate or hamper the use of a policy (Brinton et al. 2018; Haas and Hwang 2019). Mixed-methods approaches have become a useful way to fuse the strengths of quantitative and qualitative research, and to gain a comprehensive understanding of how welfare states and family policies shape family behaviour (Grunow and Evertsson 2016, 2019). 


\section{NEW DIRECTIONS IN RESEARCH ON WELFARE STATES, FAMILY POLICIES, AND FAMILY BEHAVIOUR}

\subsection{Varieties of Capitalism, Institutional Complementarities, and Family Research}

Recent developments in welfare state research and new challenges to the welfare state have led researchers to reassess and to take a broader view of the links between welfare states, family policies, and family behaviour. Esping-Andersen (1990) built his welfare regime on the interrelationship between state, market, and family in providing welfare. He focused on the state; that is, on social policies. Subsequent gender and family researchers focused on the family and on family policies. The varieties of capitalism (VOC) approach makes the market and firms the centre of analysis (Hall and Soskice 2001). It stresses that labour markets in different welfare regimes are organised differently, and that these differences may lead to differences in employment, educational, and family behaviour. Therefore, VOC researchers emphasise the need to consider 'institutional complementarities'; that is, how different institutions in welfare states complement or contradict each other.

For family sociology, the VOC approach opens up new perspectives and directions for research on welfare states, family policies, and family behaviour. It first suggests that researchers pay more attention to internal aspects of the labour market, and consider to what extent conditions at the sector, industry, company, firm, or workplace level shape family behaviour. This may be particularly necessary in liberal and hybrid welfare states, in which family and social policy benefits are largely company- or sector-specific, rather than nationally legislated (Haas and Hwang 2019). Even in conservative welfare states, there are usually differences in levels of social and family policy protection; e.g., between the public and the private sectors, and collective agreements may complement existing national statutory family policy regulations. Internal labour market conditions - such as more or less structured paths of career or employment advancement - may affect family behaviour, and lead to different family outcomes for employees in different labour market segments. To identify these effects and their driving forces, it may be necessary to more explicitly examine 'institutional complementarities', and to study how the cumulative conditions of different institutions affect family behaviour and family outcomes (Palme 2006). Such an approach may prove indispensable given the ongoing liberalisation of the labour market, and the efforts to change the welfare state into a 'social investment welfare state'.

\subsection{New Social Risks, the Social Investment Welfare State, and the Family}

Welfare state researchers generally agree that economic, demographic, social, and family-related changes have altered the conditions for welfare states, and have increased the pressure to develop new or modified welfare policies (Mills and Blossfeld 2013). Family-related shifts such as growing family complexity and increases in non-marital birth rates, union instability, and sole motherhood may give rise to 'new social risks', since such family forms are often insufficiently covered by 'traditional' social security policies (Bonoli 2005; Esping-Andersen et al. 2002). Welfare state protection is usually tied to life-long employment. These 'new social risks' are associated with circumstances that lead to interrupted, shortened, or income-reduced employment histories over the life course, such as having to take on care obligations and family work. Therefore, welfare states are increasingly changing their social policies away 
from providing 'passive' protection in the case of 'de-commodification' and towards implementing 'social investment policies'; that is, activating employment capacities through active labour market policies, the expansion of childcare and early childhood education, increases in flexible education opportunities, and the promotion of life-long learning and skills acquisition (Morel et al. 2012). From the Lisbon Strategy in 2000 to the Social Investment Package of 2013, the social policy strategies of the EU supported this restructuring of European welfare states towards the strengthening of individual human capacities and the promotion of employability throughout the life course, irrespective of an individual's or a family's situation or care obligations. This shift towards the development of 'social investment welfare states' has been accompanied by a more restrictive approach to social transfers, whereby the receipt of social benefits is increasingly tied to participation in activation or educational programmes (Hemerijck 2017; Morel et al. 2012; see also Bradshaw and Nieuwenhuis in this volume).

The turn towards a social investment welfare state poses particular challenges for the conservative-corporatist welfare states of continental Europe. Their familialism and social class differentiation is at odds with the aims of a social investment welfare state to activate people, promote work-family reconciliation, and increase levels of gender and social equality. In contrast, the Nordic countries have long pursued a social investment strategy. Their 'activating' labour market and family policies have increasingly been used as models to stimulate welfare reforms in continental Europe (Ostner and Schmitt 2008). Over the past two decades, all conservative Western European welfare states have weakened their familialism by expanding childcare provision and modifying their work-family reconciliation policies. Some of these countries took more 'path-shifting' or paradigmatic steps (e.g., Germany), while others are considered 'slow movers', and have adjusted their policies only incrementally (Morgan 2012; Moss et al. 2020; Palier 2010). So far, neither of these moves has transformed the conservative Western welfare states into work-family and equality-oriented social investment welfare states. Similar developments can be observed in Eastern European countries. The reforms these countries have implemented have increased the diversity of family policies across welfare states, and of work-care options for parents within welfare states.

Gender, family, and welfare state researchers have provided ambivalent assessments of efforts by conservative familialistic welfare states to move in the direction of social investment welfare states. While most praise the shift towards facilitating work-family reconciliation, they tend to criticise these states for neglecting equality issues at the expense of increasing employment (Jenson 2009). The focus on employment can devalue care within the family, and lead to gender inequality in care (Saraceno 2015). While childcare options have been extended, the family - which mostly means the woman in the family - still provides large and essential parts of care that cannot be fully outsourced or monetarised. With the exception of the Nordic countries, social investment welfare states do not sufficiently address this issue or the role of men in care giving. Thus, these states are forgoing the opportunity to actively transform the family into a gender-egalitarian institution, or to sufficiently tackle the new social risk of a care deficit under tightened employment requirements (Saraceno 2015).

Some gender researchers have also pointed out that the pressure to remain employed has expanded the institutionalised, private, or informal market for care and domestic work (Estévez-Abe and Hobson 2015; Hobson et al. 2018; Williams 2012). Much of this care is provided by migrant women who either live in the respective countries or work transnationally (e.g., Anderson 2012). Social investment policies do not sufficiently address the gender and ethnic inequalities that may result from the employment-focused turn in welfare policies. 
Researchers have also pointed out the 'Matthew effect' of the social investment strategies. Well-educated couples and middle- and upper-income families profit more from social investment policies than families from the lower classes, particularly if the extension of childcare and support for domestic help is accompanied by an extension of (high-quality) market-based or private services (Hobson et al. 2018; Pavolini and van Lancker 2018). This effect might also apply to active labour market policies in conservative welfare states, even though they are intended to integrate disadvantaged groups into the labour market (Bonoli and Liechti 2018). As well as reinforcing the ethnic and gender dualisation in education, labour force participation, employment, social mobility, and social protection that are characteristic of conservative welfare states (Emmenegger et al. 2012), these developments may create new dualisations in family formation. Recent research on childlessness in the Nordic countries, which are the most advanced social investment welfare states, has revealed that there are new and growing cleavages in childlessness and family formation, with people with low levels of education becoming less likely to have (long-lasting) partnerships or children (Jalovaara et al. 2019). Social inequalities in family life and family support have also increased through the development of ethnic, national and transnational, care markets (Hobson et al. 2018; Williams 2012).

Another issue concerns growing incongruences among policies that may affect families at risk in particular. The receipt of social benefits may be tied to participation in active labour market policies, irrespective of people's care obligations or whether childcare or other measures to facilitate education-care reconciliation are available. The pressure to be in life-long employment may have repercussions for family formation and family behaviour, since employment interruptions, even when taken for purposes of parental leave or care leave, may reduce social security benefit levels in old age. This issue may particularly affect individuals and families with low income and few options to increase their lifetime earnings. With their focus on promoting employment, skills advancement, and higher education, social investment strategies - but also nationally centred welfare, social, and family policies - may fail to provide protection against the 'new social risks' that families and individuals face.

The turn towards social investment welfare states calls for a broadening of research on the welfare state, family policies, family behaviour, and family outcomes. There is still relatively little research on how the shift towards social investment welfare states affects family behaviour (Busemeyer et al. 2018). The bulk of the existing research on social investment welfare states has focused on theories, ideas, approaches, and practices of macro-level issues (see, e.g., Busemeyer et al. 2018; Esping-Andersen et al. 2002; Hemerijck 2017; Morel et al. 2012). Studying the consequences of social investment-oriented policies for families is a large research area that covers single-country studies as well as comparative and especially transnational research. Investigating the consequences for families of the shift towards social investment may present specific challenges for researchers. First, the focus on the classic family policies, such as childcare and parental leave, needs to be expanded to include labour market and educational policies, and to studying how these policies affect family behaviour and family outcomes. This issue is tied to a stronger methodological recognition of 'institutional complementarities'. Second, researchers need to consider incremental changes or changes in policy instruments and conditions. This also means examining whether the shift towards social investment creates incongruences among policies, and how such incompatibilities affect family formation or family outcomes in general, across classes, and across different family life courses. Third, researchers should pay specific attention to 'new social risk' families and to the policies that are directed at them. Given the shift away from providing passive social 
assistance and towards implementing activating social investment policies (see Bradshaw and Nieuwenhuis in this volume), researchers will need to overcome the boundaries between family research that focuses on poverty, and family research that focuses on welfare states and family policies. Fourth, this trend will mean that transnational studies will be needed that examine how welfare and family policies affect the family behaviour and family outcomes of those who migrate or move between welfare states (see also Andersson in this volume).

\subsection{Welfare State, Crises, and the Family}

The recent global Great Recession that started in 2007 has spurred research on the link between economic crises and family behaviour (Comolli et al. 2021; Goldstein et al. 2013; Kreyenfeld et al. 2012; Sobotka et. al. 2011). A general finding of these studies is that economic uncertainty brought about by an economic crisis or by individual unemployment tends to negatively affect fertility, union formation, and union stability. This effect may vary across recession periods, countries, age groups, and social and educational strata (ibid.). The effects of crises on family behaviour are usually attributed to economic factors, and, in particular, to the decline in or loss of income. Researchers maintain that the impact of a crisis on family behaviour may vary across welfare regimes (e.g., Sobotka et al. 2011). Studies that investigate the links between welfare regimes, family policies, and family behaviour during a crisis are still rare; and those that exist seem to corroborate these assumptions. For example, Kreyenfeld and Andersson (2014) found that unemployment reduces a man's propensity to become a father more in Germany than in Denmark. They attributed this difference to the male-breadwinning focus of the German welfare state and the dual-earner focus of the Danish welfare state. The gap in the fertility developments after the economic crisis of the 1990s in Sweden and Finland is an example of how different family policies may lead to different family behaviours during an economic crisis.

Recent research findings suggest that to ensure that analyses of effects of crises on families are adequate, the welfare state and family policy framework should be extended to include labour market restructuring, crisis management, and welfare state reactions during and after a crisis. All economic crises affect the labour market and the welfare state. The Covid-19 pandemic that hit Europe in the spring of 2020 has demonstrated that this is also the case for health crises. Seltzer (2019) showed that it is not a crisis as such, but rather the labour market restructurings caused by the crisis that tend to affect family behaviour. Comolli et al. (2021) argued that in addition to labour market restructuring, welfare state reactions to the crisis may have shaped family behaviour. For example, whether social security, parental leave, and family or other benefits are cut, maintained, or increased during a crisis may result in different family behaviours and different family outcomes. Similarly, whether social investment policies, such as active labour market policies, skills training, or educational opportunities are expanded during and after a crisis - or whether the crisis management consists primarily of passive transfers to those who lost their employment or slid into poverty - may have different effects on family behaviour. Ólafsson et al. (2019) provided lucid examples of how governmental reactions to the Great Recession mattered for curbing the vulnerability of risk groups and families during and after the crisis. Thus, family research that considers the welfare state and family policy context, as well as how welfare states, labour markets, and firms react to a crisis, may provide deeper insight into the links between crises and their effects on families in general, and by region, composition, socio-economic capacity, than the more common, 
income-focused research approaches. The use of such comprehensive approaches seems necessary to understand the impact of the current Covid-19 pandemic on families in different European countries, and to learn from this crisis in order to prepare for future crises. Without accounting for the wide variety of regulations and policies implemented to tackle the health and economic consequences of the pandemic, researchers might miss essential aspects that shape family behaviour and family outcomes during and after the crisis.

\section{CONCLUSION}

The development of research on welfare states, family policies, family behaviour, and family outcomes has provided rich insights into how institutional configurations and conditions shape families. This review has touched on only a small subset of this research. The new challenges to and the restructuring of welfare states require researchers to both review the theoretical foundations on which the concepts of welfare regimes are built, and to investigate empirically how the shifts in welfare states away from providing protection in case of de-commodification and towards mobilising employment capacities are affecting families. This will require researchers to pay attention to how class, gender, ethnic, and transnational issues are intertwined in providing welfare. Class has become more relevant due to the different levels of integration of families with migration backgrounds across welfare states. Moreover, our understanding of gender is shifting as women and men take on new roles and experience new demands. Ethnic issues have become more complex due to recent waves of immigration, and the transnational aspects of families have become increasingly important through the emergence of new care regimes in Europe. With its differentiating perspectives on individuals, their relationships, and their social and economic standing, family research is well placed to investigate the effects the new developments in welfare states and family policies may have on European societies. Family sociology's individual-level focus and strengths in performing life course analyses and social and gender stratification can bring a missing but crucial dimension to the welfare state and family policy research field, and to the political and scientific discourse on the direction and effects of European welfare states.

\section{REFERENCES}

Anderson, A. (2012), 'Europe's care regimes and the role of migrant care workers within them', Population Ageing, 5, 135-46. doi:10.1007/s12062-012-9063-y.

Andersson, G., A.-Z. Duvander, and K. Hank (2004), 'Do child-care characteristics influence continued child bearing in Sweden? An investigation of the quantity, quality, and price dimension', Journal of European Social Policy, 14 (4), 407-18. doi.org/10.1177/0958928704046881.

Arts, W. and J. Gelissen (2002), 'Three worlds of welfare capitalism or more? A state-of-the-art report', Journal of European Social Policy, 12 (2), 137-58. doi.org/10.1177/0952872002012002114.

Arts, W. and J. Gelissen (2010), 'Models of the welfare state', in F.G. Castles, S. Leibfried, J. Lewis, H. Obinger, and C. Pierson (eds), The Oxford Handbook of the Welfare State, Oxford: Oxford University Press, pp. 569-83. doi:10.1093/oxfordhb/9780199579396.003.0039.

Blum, S., J. Kuhlmann, and K. Schubert (eds) (2019), Routledge Handbook of European Welfare Systems, London: Routledge. doi.org/10.4324/9780429290510.

Bonoli, G. (2005), 'The politics of the new social policies: Providing coverage against new social risks in mature welfare states', Policy and Politics, 33 (3), 431-49. doi:10.1332/0305573054325765. 
Bonoli, G. and F. Liechti (2018), 'Good intentions and Matthew effects: Access biases in participation in active labour market policies', Journal of European Public Policy, 25 (6), 894-911. doi.org/10.1080/ 13501763.2017.1401105.

Brinton, M.C., X. Bueno, L. Oláh, and M. Mellum (2018), 'Postindustrial fertility, ideals, intentions, and gender inequality: A comparative qualitative analysis', Population and Development Review, 44 (2), 281-309. doi.org/10.1111/padr.12128.

Busemeyer, M.R., C. de la Porte, J.L. Garritzmann, and E. Pavolini (2018), 'The future of the social investment state: Politics, policies, and outcomes', Journal of European Public Policy, 25 (6), 801-9. doi.org/10.1080/13501763.2017.1402944.

Castles, F.G., S. Leibfried, J. Lewis, H. Obinger, and C. Pierson (eds) (2010), The Oxford Handbook of the Welfare State, Oxford: Oxford University Press. doi:10.1093/oxfordhb/9780199579396.001.0001.

Cerami, A. and P. Vanhyusse (eds) (2009), Post-Communist Welfare Pathways: Theorizing Social Policy Transformation in Central and Eastern Europe, Basingstoke: Palgrave Macmillan.

Comolli, C., G. Neyer, G. Andersson, L. Dommermuth, P. Fallesen, M. Jalovaara, A.K. Jónsson, M. Kolk, and T. Lappegård (2021), 'Beyond the economic gaze. Childbearing during and after recessions in the Nordic countries', European Journal of Population (online first).

Daly, M. and E. Ferragina (2018), 'Family policy in high-income countries: Five decades of development', Journal of European Social Policy, 28 (3), 255-70. doi:10.1177/0958928717735060.

Duvander, A.-Z. and M. Johansson (2012), 'What are the effects of reforms promoting fathers' parental leave use?', Journal of European Social Policy, 22 (3), 319-30. doi.org/10.1177/0958928712440201.

Duvander, A.-Z., T. Lappegård, S.N. Andersen, Ó. Garðarsdóttir, G. Neyer, and I. Viklund (2019), 'Parental leave policies and continued childbearing in Iceland, Norway, and Sweden', Demographic Research, 40 (51), 1501-28. doi:10.4054/DemRes.2019.40.51.

Emmenegger, P., S. Häusermann, B. Palier, and M. Seeleib-Kaiser (eds) (2012), The Age of Dualization: The Changing Face of Inequality in Deindustrializing Societies, Oxford: Oxford University Press. doi: 10.1093/acprof:oso/9780199797899.001.0001.

Esping-Andersen, G. (1990), The Three Worlds of Welfare Capitalism, Princeton, NJ: Princeton University Press.

Esping-Andersen, G. (1999), Social Foundations of Postindustrial Economies, Oxford: Oxford University Press.

Esping-Andersen, G., D. Gallie, A. Hemerijk, and J. Myers (2002), Why We Need a New Welfare State, Oxford: Oxford University Press. doi:10.1093/0199256438.001.0001.

Estévez-Abe, M. and B. Hobson (2015), 'Outsourcing domestic (care)work: The politics policies and political economy', Social Politics, 22 (2), 133-46. doi.org/10.1093/sp/jxv011.

Eydal, G. and T. Rostgaard (eds) (2018), Handbook of Family Policies, Cheltenham, UK and Northampton, MA, USA: Edward Elgar Publishing. doi.org/10.4337/9781784719340.

Ferrarini, T. (2006), Families, States and Labour Markets. Institutions, Causes and Consequences of Family Policy in Post-War Welfare States, Cheltenham, UK and Northampton, MA, USA: Edward Elgar Publishing.

Ferrera, M. (1996), 'The Southern welfare state in social Europe', Journal of European Social Policy, 6 (1), 17-37. doi.org/10.1177/095892879600600102.

Flora, P. and A. Heidenheimer (eds) (1982a), The Development of Welfare States in Europe and America, New Brunswick, NJ: Transaction Publishers.

Flora, P. and A. Heidenheimer (1982b), 'The historical core and changing boundaries of the welfare state', in P. Flora and A. Heidenheimer (eds), The Development of Welfare States in Europe and America, New Brunswick, NJ: Transaction Publishers, pp. 17-34.

Gauthier, A. (2002), 'Family policies in industrialized countries: Is there convergence?', Population (English selection), 57 (3), 457-84. doi: 10.2307/3246635.

Goldstein, J., M. Kreyenfeld, A. Jasilioniene, A., and D.D.K. Örsal (2013), 'Fertility reactions to the Great Recession in Europe: Recent evidence from order-specific data', Demographic Research, 29 (4), 85-104. doi:10.4054/DemRes.2013.29.4.

Gornick, J. and M.K. Meyers (eds) (2003), Families That Work: Policies for Reconciling Parenthood and Employment, New York: Russell Sage Foundation. 
Gornick, J. and T. Smeeding (2018), 'Redistributional policy in rich countries: Institutions and impacts in nonelderly households', Annual Review of Sociology, 44, 441-68. doi.org/10.1146/annurev-soc $-073117-041114$.

Greve, B. (ed.) (2019), Routledge Handbook of the Welfare State, 2nd edition, London: Routledge. doi .org/10.4324/9781315207049.

Grunow, D. and M. Evertsson (eds) (2016), Couples' Transitions to Parenthood: Analysing Gender and Work in Europe, Cheltenham, UK and Northampton, MA, USA: Edward Elgar Publishing. doi.org/ $10.4337 / 9781785366000$.

Grunow, D. and M. Evertsson (eds) (2019), New Parents in Europe: Work-Care Practices, Gender Norms and Family Policies, Cheltenham, UK and Northampton, MA, USA: Edward Elgar Publishing. doi.org/10.4337/9781788972970.

Haas, L. and C.P. Hwang (2019), 'Workplace support and European fathers' use of state policies promoting shared childcare', Community, Work and Family, 21 (2), 1-22. doi.org/10.1080/13668803 .2018.1556204.

Hall, P.A. (1993), 'Policy paradigms, social learning, and the state: The case of economic policymaking in Britain', Comparative Politics 25 (3), 275-296. doi:10.2307/422246.

Hall, P.A. and D. Soskice (eds) (2001), Varieties of Capitalism: The Institutional Foundations of Comparative Advantage, Oxford: Oxford University Press. doi:10.1093/0199247757.001.0001.

Hemerijck, A. (ed.) (2017), The Uses of Social Investment, 1st edition, Oxford: Oxford University Press. doi:10.1093/oso/9780198790488.001.0001.

Hernes, H.M. (1987), Welfare State and Woman Power: Essays in State Feminism, Oslo: Norwegian University Press.

Hobson, B. and S. Fahlén (2009), 'Competing scenarios for European fathers: Applying Sen's capabilities and agency framework to work-family balance', Annals of the American Academy of Political and Social Science, 624, 214-33. doi.org/10.1177/0002716209334435.

Hobson, B., Z. Hellgren, and I. Serrano (2018), 'Migrants, markets and domestic work: Do institutional contexts matter in the personal household service sector?', Journal of European Social Policy, 28 (4), 386-401. doi.org/10.1177/0958928717753578.

Hoem, J.M. (1993), 'Public policy as the fuel of fertility: Effects of a policy reform on the pace of childbearing in Sweden', Acta Sociologica, 36, 19-31. doi.org/10.1177/000169939303600102.

Hoem, J.M. (2008), 'Overview chapter 8: The impact of public policies on European fertility', Demographic Research, 19, 249-60. doi:10.4054/DemRes.2008.19.10.

Jalovaara, M., G. Neyer, G. Andersson, J. Dahlberg L. Dommermuth, P. Fallesen, and T. Lappegård (2019), 'Education, gender, and cohort fertility in the Nordic countries', European Journal of Population, 35, 563-86. doi.org/10.1007/s10680-018-9492-2.

Jenson, J. (2009), 'Lost in translation: The social investment perspective and gender equality', Social Politics: International Studies in Gender, State and Society, 16 (4), 446-83. doi:10.1093/sp/jxp019.

Kamerman, S. and A.J. Kahn (eds) (1978), Family Policy: Government and Families in Fourteen Countries, New York: Columbia University Press.

Kessler-Harris, A., J. Lewis, and U. Wikander (1995), 'Introduction', in U. Wikander, A. Kessler-Harris, and J. Lewis (eds), Protecting Women: Labor Legislation in Europe and the United States and Australia, 1880-1920, Urbana, IL: University of Illinois Press, pp. 1-27.

Kickbusch, I. and B. Riedmüller (eds) (1984), Die armen Frauen. Frauen und Sozialpolitik, Frankfurt a.M.: Suhrkamp Verlag.

Knijn, T. and M. Kremer (1997), 'Gender and the caring dimension of welfare states: Toward inclusive citizenship', Social Politics, 4 (3), 328-61. doi.org/10.1093/oxfordjournals.sp.a034270.

Korpi, W. (2000), 'Faces of inequality: Gender, class, and patterns of inequalities in different types of welfare states', Social Politics: International Studies in Gender, State and Society, 7 (2), 127-91. doi: 10.1093/sp/7.2.127.

Korpi, W., T. Ferrarini, and S. Englund (2013), 'Women's opportunities under different family policy constellations: Gender, class, and inequality tradeoffs in Western countries re-examined', Social Politics, 20 (1), 1-40. doi:10.1093/sp/jxs028.

Kreyenfeld, M. and G. Andersson (2014), 'Socioeconomic differences in the unemployment and fertility nexus: Evidence from Denmark and Germany', Advances in Life Course Research, 21, 59-73. doi .org/10.1016/j.alcr.2014.01.007. 
Kreyenfeld, M., G. Andersson, and A. Pailhé (eds) (2012), 'Economic uncertainty and family dynamics in Europe', Demographic Research Special Collection, 12. www.demographic-research.org/special/ $12 /$ default.htm.

Lalive, R. and J. Zweimüller (2009), 'How does parental leave affect fertility and return to work? Evidence from two natural experiments', Quarterly Journal of Economics, 124 (9), 1363-402. doi .org/10.1162/qjec.2009.124.3.1363.

Langan, M. and I. Ostner (1991), 'Geschlechterpolitik im Wohlfahrtsstaat: Aspekte im internationalen Vergleich', Kritische Justiz, 24 (3), 302-17. doi.org/10.5771/0023-4834-1991-3.

Leitner, S. (2003), 'Varieties of familialism: The caring function of the family in comparative perspective', European Societies, 5 (4), 353-75. doi.org/10.1080/1461669032000127642.

Leitner, S. (2011), 'Germany outpaces Austria in childcare policy: The historical contingencies of “conservative" childcare policy', Journal of European Social Policy, 20 (5), 456-67. doi.org/10.1177/ 0958928710380482.

Lewis, J. (1992), 'Gender and the development of welfare regimes', Journal of European Social Policy, 2 (3), 159-73. doi.org/10.1177/095892879200200301.

Mandel, H. and M. Semyonov (2005), 'Family policies, wage structures, and gender gaps: Sources of earnings inequality in 20 countries', American Sociological Review, 70 (6), 949-67. doi:10.1177/ 000312240507000604.

Mayer, K.-U. and U. Schöpflin (1989), 'The state and the life course', Annual Review of Sociology, 15, 187-209. doi.org/10.1146/annurev.so.15.080189.001155.

Mills, M. and H.P. Blossfeld (2013), 'The second demographic transition meets globalization: A comprehensive theory to understand changes in family formation in an era of rising uncertainty', in A. Evans and J. Baxter (eds), Negotiating the Life Course: Stability and Change in Life Pathways, Dordrecht: Springer, pp. 9-33. doi.10.1007/978-90-481-8912-0_2.

Morel, N., M. Palier, and J. Palme (eds) (2012), Towards a Social Investment Welfare State? Ideas, Policies and Challenges, Bristol: Policy Press. doi:10.1332/policypress/9781847429247.001.0001.

Morgan, K.J. (2012), 'Promoting social investment through work-family policies: Which nations do it and why', in N. Morel, B. Palier, B. and J. Palme (eds), Towards a Social Investment Welfare State? Ideas, Policies and Challenges, Bristol: Policy Press, pp. 153-79. doi:10.1332/policypress/ 9781847429247.003.0006.

Moss, P., A.-Z. Duvander, and A. Koslowski (eds) (2020), Parental Leave and Beyond: Recent International Development, Current Issues and Future Directions, Bristol: Policy Press. doi:10.1332/ policypress/9781447338772.001.0001.

Neyer, G. and G. Andersson (2008), 'Consequences of family policies on childbearing behavior: Effects or artifacts?', Population and Development Review, 34 (4), 699-724. doi:10.1111/j.1728-4457.2008 .00246.x.

Ólafsson, S., M. Daly, O. Kangas, and J. Palme (eds) (2019), Welfare and the Great Recession: A Comparative Study, Oxford: Oxford University Press. doi:10.1093/oso/9780198830962.001.0001.

Orloff, A.S. (1993), 'Gender and the social rights of citizenship: The comparative analysis of gender relations and welfare states', American Sociological Review, 58 (3), 303-28. doi:10.2307/2095903.

Ostner, I. and C. Schmitt (eds) (2008), Family Policies in the Context of Family Change: The Nordic Countries in Comparative Perspective, Wiesbaden: VS Verlag für Sozialwissenschaften. doi:10.1007/ 978-3-531-90895-3.

Palier, B. (ed.) (2010), A Long Goodbye to Bismarck? The Politics of Welfare Reform in Continental Europe, Amsterdam: Amsterdam University Press.

Palme, J. (2006), 'Welfare states and inequality: Institutional designs and distributive outcome', Research in Social Stratification and Mobility, 24 (4), 387-403. doi.org/10.1016/j.rssm.2006.10.004.

Pavolini, E. and W. Van Lancker (2018), 'The Matthew effect in childcare use: A matter of policies or preferences?', Journal of European Public Policy, 25 (6), 878-93. doi.org/10.1080/13501763.2017 .1401108 .

Pfau-Effinger, B. (1998), 'Gender cultures and the gender arrangement: A theoretical framework for cross-national gender research', Innovation: The European Journal of Social Science Research, 11 (2), 147-66. doi:10.1080/13511610.1998.9968559.

Pfau-Effinger, B. (2005), 'Culture and welfare state policies: Reflections on a complex interaction', Journal of Social Policy, 34 (1), 3-20. doi.org/10.1017/S0047279404008232. 
Pierson, P. (2001), 'Coping with permanent austerity: Welfare state restructuring in affluent democracies', in P. Pierson (ed.), The New Politics of the Welfare State, Oxford: Oxford University Press. doi: 10.1093/0198297564.003.0014.

Przeworski, A. and H. Teune (1970), The Logic of Comparative Social Inquiry, New York: Wiley.

Robila, M. (ed.) (2014), Handbook of Family Policies around the Globe, New York: Springer. doi:10 .1007/978-1-4614-6771-6777.

Rostgaard, T. (2018), 'Childcare as a global policy agenda', in G.E. Eydal and T. Rostgaard (eds), Handbook of Family Policy, Cheltenham, UK and Northampton, MA, USA: Edward Elgar Publishing, pp. 96-110. doi.org/10.4337/9781784719340.

Sainsbury, D. (ed.) (1999), Gender and Welfare State Regimes, Oxford: Oxford University Press. doi:10 $.1093 / 0198294166.001 .0001$.

Saraceno, C. (ed.) (2008), Families, Ageing and Social Policy: Intergenerational Solidarity in European Welfare States, Cheltenham, UK and Northampton, MA, USA: Edward Elgar Publishing.

Saraceno, C. (2015), 'A critical look to the social investment approach from a gender perspective', Social Politics, 22 (2), 257-69. doi: 10.1093/sp/jxv008.

Saraceno, C. (2016), 'Varieties of familialism: Comparing four southern European and East Asian welfare regimes', Journal of European Social Policy, 26 (4), 314-26. doi.org/10.1177/0958928716657275.

Saraceno, C. and W. Keck (2010), 'Can we identify intergenerational policy regimes in Europe?', European Societies, 12 (5), 675-96. http://dx.doi.org/10.1080/14616696.2010.483006.

Saxonberg, S. and T. Sirovátka (2006), 'Failing family policy in post-communist Central Europe', Journal of Comparative Policy Analysis: Research and Practice, 8, 185-202. doi.org/10.1080/ 13876980600682089.

Seltzer, N. (2019), 'Beyond the Great Recession: Labor market polarization and ongoing fertility decline in the United States', Demography, 56, 1-31. doi.org/10.1007/s13524-019-00790-6.

Shaver, S. (ed.) (2018), Handbook on Gender and Social Policy, Cheltenham, UK and Northampton, MA, USA: Edward Elgar Publishing. doi:10.4337/9781785367168.

Sobotka, T., V. Skirbekk, and D. Philipov (2011), 'Economic recession and fertility in the developed world', Population and Development Review, 37 (2), 267-306. doi.org/10.1111/j.1728-4457.2011 .00411.x.

Thelen, K. (1999), 'Historical institutionalism in comparative politics', Annual Review of Political Science, 2, 369-404. doi.org/10.1146/annurev.polisci.2.1.369.

Thévenon, O. (2011), 'Family policies in OECD countries: A comparative analysis', Population and Development Review, 37 (1), 57-87. doi.org/10.1111/j.1728-4457.2011.00390.x.

Wilensky, H. (1975), The Welfare State and Equality: Structural and Ideological Roots of Public Expenditure, Berkeley, CA: University of California Press.

Williams, F. (2012), 'Converging variations in migrant care work in Europe', Journal of European Social Policy, 22 (4), 363-76. doi.org/10.1177/0958928712449771. 